\section{EREM 76/1}

Journal of Environmental Research, Engineering and Management Vol. 76 / No.2 / 2020 pp. $91-110$ DOI 10.5755/j01.erem.76.2.25490
The Application of a Proposed Risk Assessment Approach on Rock Failure Hazard on Manshiet Nasser District

Received 2020/03 Accepted after revision 2020/06

\title{
The Application of a Proposed Risk Assessment Approach on Rock Failure Hazard on Manshiet Nasser District
}

\section{Donia Fakhri Abdel Monem*}

Environmental Planning Department, Faculty of Urban and Regional Planning, Cairo University, Teaching Assistant, Cairo University Campus, Gamaa Street, Giza, Egypt

\section{Heba Nabil Abdel Hamed}

Environmental Planning Department, Faculty of Urban and Regional Planning, Cairo University, Lecturer, Cairo University Campus, Gamaa Street, Giza, Egypt

\section{*Corresponding author: doni7.fa5ri@yahoo.com}

Rock failure is one of the most geomorphological hazards that cause considerable damages in different regions every year. To effectively mitigate this hazard, new methodologies are needed to develop a better understanding of rock failure assessment and management. In recent years, risk analysis and assessment have become an important tool in addressing uncertainty. However, the all-embracing perspective of the notion of risk is not an easy task to undertake since it requires data availability at different scales and a multidisciplinary point of view. The research aims to analyse the factors causing the occurrence of rock failure by analysing hazard and vulnerability factors using a proposed risk assessment approach to be applied on Mansheit Nasser district. The research uses a quantitative analytical risk assessment methodology. The methodology used to assess the risk of rock failure in Mansheit Nasser district is to estimate the hazard $(\mathrm{H})$ and the vulnerability $(\mathrm{V})$. The risk is calculated by using equations mentioned in the research and the arc GIS programme to prepare maps. The equation is used to standardise the value of risk factors and unify their weights. The research concludes that the rock failure risk index (RFRI) determines the most vulnerable areas to rock failure in Manshiet Nasser to estimate the elements at risk (E).

Keywords: rock failure, landslide, risk assessment, vulnerability assessment, Manshiet Nasser. 


\section{Introduction}

The research aims to analyse the factors that cause the occurrence of rock failure. It helps to estimate the severity of risks and analyse the vulnerability factors for identifying risk elements of rock failure. The proposed methodology is drawn from the review of several previous researches, to help solve the deficiencies in the previous risk assessment methodologies, which omitted the input identification of rock failure risk assessment. This methodology will be applied on Mansheit Nasser District using the GIS programme to extract and prepare maps and equations.

Risk is the probability and the amount of harmful consequences or expected losses resulting from interactions between natural or human induced hazards and vulnerable conditions (UN/ISDR, 2004). Rock failure hazards include rockfall and landslide. Landslide is a natural hazard that may produce deaths, injuries, and direct and indirect economic losses, so it is important to take them into account in town and country planning aiming to reduce these consequences (Guillard and Zezere, 2012). Rockfall means falling blocks of rocks sequentially. Figure 1 shows the difference between landslide and rockfall.

Fig. 1. The difference between landslide and rockfall

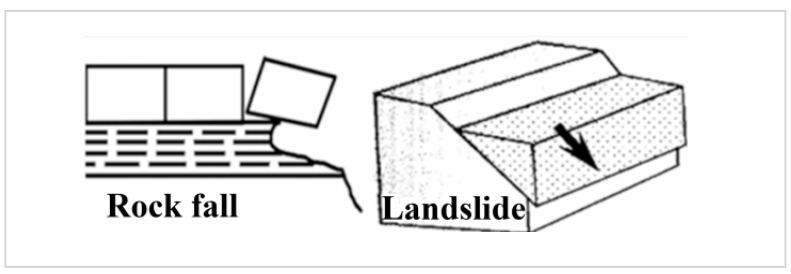

The risk assessment process is the decision making process. It detects whether the existing risks are possible or not, and whether the measures to address such risks are adequate or not. If the answer is negative, the alternative measures have to be implemented (Fell et al., 2005). The rock failure risk assessment has a great importance in decision-making processes, where risk management process depends basically on critical information from risk assessment. The urban areas in Egypt are affected mostly by the occurrence of rock failure. As a result of the imbalance between land use and geo-environmental hazards, there is a relative neglect of the impact of geo-environmental risks on urban areas in Egypt. The applied methodologies for assessing the risk of rock failure for urban areas in Egypt are not appropriate, because these risks are met in limited spatial conditions and technical engineering methods.

Some studies tackle the field of rock collapse risk assessment. Roslee et al. (2017) suggested a methodology for calculating and estimating the hazard only, but it neglected the vulnerability assessment that makes the evaluation of results inaccurate. Another research tackled the assessment of risk by proposing an approach to determine hazard assessment of inputs and outputs, but it did not specify the vulnerability assessment of inputs and outputs (Effat and Hegazy, 2014). Mrozek et al. (2016) proposed that the future rock failure will have causal factors such as rock failure in the past, so it is hard to apply this approach because the selected region has not had previous rock failure. Papathoma et al. (2007) suggested a methodology for assessing the risk of rock failure by focusing on calculating the vulnerability of population and urban areas, but this approach did not consider the specificity of the inputs of risk assessment and omit the severity of hazard. According to the indicators, criteria and stages resulting from the analysis of previous researches are combined in one proposed approach to solve the defects.

\section{Factors causing and triggering the occurrence of rock failure}

The assessment process is affected by several factors. These factors are the causal and motivational factors of rock failure occurrence, the size of available data, the size of the study area, and the type of ancient and modern rock failure occurring in the area in question. The factors of rock failure include:

Environmental factors: geology, geomorphology, soil, topography, hydrological study and land cover;

Topographic attributes have been identified as the most important factor in controlling the initiation and distribution of landslides and rock failure (Zhang et al., 2012); Causing and motivating factors: earthquakes, volcanoes and rain; 
Elements at risk: buildings, urbanisation, road network and basic facilities;

Urban characteristics: construction materials, age of building, number of floors and number of households in each building;

Hazard characteristics: historical record, types of constituents, and pattern of movement and repetition;

Socio-economic factors, like increasing population and concentrations of settlements on endangered areas (Azzam et al., 2010); and

Anthropogenic activities and land use: the explosives, used for quarry activities, cause cracks, fractures and faults activation, which in turn increase the rate of block movement, and the rock excavation process in these quarries that creates unstable vertical cliffs (Khaled et al., 2008).

\section{Materials and Methods}

The maps, aerial photographs and reports of the study area, such as topographic and geological maps, are collected and analysed to identify the most important characteristics of rock failure and land use. The ArcGIS programme is used for this process because of its high accuracy in doing analysis. The research focuses on spatial analysis to ensure saving time and effort. It proposes many ways to assess the risk of rock failure depending on the study area, research methods, study objective and physical possibilities.

SRTM satellite data is used to derive elevation, slope angles and flow network using the ArcGIS software.

The analysis was performed in the study area (approximately $4.52 \mathrm{~km}^{2}$ ). The study area was divided into cells $(10 \mathrm{~m} \times 10 \mathrm{~m}$ ) (a total of 45,723 pixels).

Standardising the measurement and determination of the weights of causal and motivating factors

Rock failure is considered a complex operation because of the lack of a complete historical record on the one hand and the difficulty of identifying the causative factors on the other hand. They are different according to the specificity of each region (Pareta and Kumar, 2012). A distinction must be made between the immediate and long-term factors of rock failure. The immediate causes include vibrations (such as those caused by the passage of trains, trucks or earthquakes) and heavy rains, while the long-term causes include gradual and slow change in slope. The common difficulty in each multi-criteria analysis is the number of factors to consider. There are many factors that cause rock failure, but the factors chosen for this approach are shown in Figure 2.

Fig. 2. Factors causing and triggering the occurrence of rock failure chosen for the proposed approach

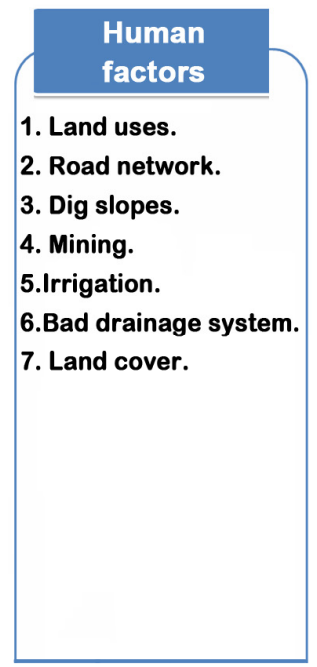

$\begin{aligned} & \text { Hydrogeographic } \\ & \text { factors }\end{aligned}$
1. Flow direction.
2. Catchment area
and rainfall intensity.
3. Flow accumulation.
4. Water channels.
5.Water streams net-
work.
6.Topographic humidity
index.

Geomorphological
factors
1. Map of gradient
angles.
2. Curvature map.
3. Geomorphological
map.
4. Aspect map.
5.Terrain roughness
index.
6. Classification of land
cover or terrain.
7. The presence of
volcanic movement.
8. Ice movement.
9. Earthquakes.

Geological

factors

1. Rock characteristics.

2. Soil type.

3. Faults.

4. Terrain.

5. Distance from faults.

6. Distance from the center of volcanoes.

7. Variation in permeability and hardness of constituent materials. 8. Slope degree and slope height. 
The risk of rock failure is assessed by calculating a combination of non-similar factors in the measuring method. The type and nature of the rock layer are qualitative or descriptive, while the slope inclination is an angle measured by degrees (Effat and Hegazy, 2014). The factors were converted into a scale from 0 to 1 degree of vulnerability according to the following equation (1) (Effat and Hegazy, 2014). This method was selected due to its simplicity to be applied. Table 1 shows an example of relative weights using the linear transform numerical calculation and setting (Effat and Hegazy, 2014).

Table 1. Relative weights using the linear transform numerical calculation and setting

\begin{tabular}{|c|c|c|c|c|}
\hline Factors & Rank & $\begin{array}{l}\text { Weight } \\
(n-r j+1)\end{array}$ & $\begin{array}{l}\text { Normal weight of } \\
\text { the factor }=(n-r j+1) / \\
\text { sum }(n-r j+1)\end{array}$ & $\begin{array}{c}\text { Weight } \\
\%\end{array}$ \\
\hline Lithology & 1 & 9 & 0.200 & 20 \\
\hline Slope & 2 & 8 & 0.178 & 17.8 \\
\hline $\begin{array}{l}\text { Density of } \\
\text { faults }\end{array}$ & 3 & 7 & 0.156 & 15.6 \\
\hline $\begin{array}{l}\text { Seismic } \\
\text { intensity }\end{array}$ & 4 & 6 & 0.133 & 13.3 \\
\hline $\begin{array}{l}\text { Land } \\
\text { cover }\end{array}$ & 5 & 5 & 0.111 & 11.1 \\
\hline Soil & 6 & 4 & 0.089 & 8.9 \\
\hline $\begin{array}{l}\text { Density } \\
\text { of water } \\
\text { streams }\end{array}$ & 7 & 3 & 0.067 & 6.7 \\
\hline $\begin{array}{l}\text { Rugged } \\
\text { terrain }\end{array}$ & 8 & 2 & 0.044 & 4.4 \\
\hline Height & 9 & 1 & 0.022 & 2.2 \\
\hline
\end{tabular}

$W_{j}=\frac{\left(n-r_{j}+1\right)}{\sum\left(n-r_{k}+1\right)}$

Where: $W_{j}$ is the normal weight of the factor;

$\mathrm{n}$ is the number of factors taken into consideration of the total rank;

$r_{j}$ is the order of the factor and its rank;

$\sum\left(n-r_{k}+1\right)$ is the total sum of weight.
The weighted linear combination (WLC) method is used to combine factors where the landslide susceptibility index (LSI) of each pixel is calculated by adding the weight of each factor multiplied by the weight of the layer as shown in equation (2) (Effat and Hegazy, 2014):

$\mathrm{LSI}=\Sigma\left(\mathrm{W}_{\mathrm{j}} \mathrm{X}_{\mathrm{ij}}\right)$

(Zhou et al., 2016; Kanungo and Sarkar, 2004)

Where: LSI is the landslide susceptibility index of a specified pixel;

$W_{j}$ is the weight of factor $j$;

$X_{i j}$ is the classification (standard value) of class $i$ in factor $\mathrm{j}$;

$\mathrm{N}$ is the total number of factors.

\section{General equation for calculating and assessing risks}

Equation (3) is used and applied on all types of risks, but the difference lies in the method of calculating and assessing the hazard according to its type. The risk calculations are changed according to the type, duration, start and end time, risk intensity, extension, and spatial impact (Westen, 2014). The vulnerability is expressed in a digital scale of 0:1.

$\mathrm{R}=\mathrm{H} \times \mathrm{V} \times \mathrm{E}$

Where: $\mathrm{H}$ is hazard;

$V$ is vulnerability;

$E$ is elements at risk;

$\mathrm{R}$ is risk assessment.

Risk refers to measuring the probability and severity of an adverse effect on life, health, property, or the environment quantitatively (Fell et al., 2005). Risk assessment is the entire process of analysing risk and evaluating results according to the risk tolerance criteria (Vinnem and Røed, 2019).

Hazard refers to the probability that a particular danger (threat) occurs within a given period of time. (Costard, 2008).

Vulnerability refers to the potential degree of loss (damage) to a given element or risk elements that result from the occurrence of a natural phenomenon of a given magnitude. Vulnerability is expressed on a numerical scale from 0 (no damage) to 1 (total damage) (Roslee et al., 2017). 
Elements at risk are population, buildings and engineering works, infrastructure, environmental features, and economic activities in the area affected by a hazard (Fell et al., 2005).

\section{Calculation of vulnerability}

The calculation is formulated through the development of a database of vulnerable elements (population and urban areas), as well as the history of previous rock failure done by field surveys. The factors causing rock failure in urban areas that are identified as hazardous highly are determined, and a database is created including factors of rock failure occurrence: physical factors (building materials);

social status (injuries, deaths, safety, loss of housing and public awareness); and

effect on the environment (impact period and daily management).

Moreover, the values are generated for all vulnerability elements of rock failure ranging from 0:1, as shown in Table 2.

Table 2. Vulnerability values of elements at Risk

\begin{tabular}{c|c}
\hline Value & Damage / vulnerability percentage \\
\hline 0 & $0 \%$ \\
\hline 0.25 & $1 \%: 25 \%$ \\
\hline 0.50 & $26 \%: 50 \%$ \\
\hline 0.75 & $51 \%: 75 \%$ \\
\hline 1 & $76 \%: 100 \%$ \\
\hline
\end{tabular}

The rock failure distribution map is used to analyse the factors to generate a vulnerability degree map, where it is produced based on field studies and satellite image interpretations in order to determine the locations of rock failure in the study area. The linear transform numerical calculation is used to reanalyse this data starting from 0.00 to 1.00 by applying equation (4) and its example in Table 3 (Roslee et al., 2017):

Standardization method $=\frac{\text { Raw }}{\text { Raw data maximum }}$
Table 3. Example of the method of standardisation of measurement

\begin{tabular}{l|c|c|c|c}
\hline & $a$ & $b$ & $c$ & $d$ \\
\hline Raw data & 12 & 65 & 8 & $134^{\mathrm{Max}}$ \\
\hline Standardisation & 0.090 & 0.485 & 0.060 & 1.000 \\
\hline
\end{tabular}

\section{Application of methodology on Manshiet Nasser (study area)}

Manshiet Nasser is situated on the rocky slopes of the Mouktam Hills range, which forms an eastern physical boundary to Cairo city; it was the main source of limestone used in the construction of buildings in old Cairo before the use of red bricks and concrete. It was completely empty of housing except for some nests in the western part of the highway. At the end of the 1960s, the area began to witness an intensive displacement of the population to the old quarries in Manshiet Nasser, as they began to build houses indiscriminately without considering the stone quarries and leaving any safety distance to consider the geological situation. The buildings had no public sanitation and the population used to drain directly on the rocks. These factors affected the degree of cohesion and led to the occurrence of several landslides that killed several inhabitants. The most famous rock failure dated 1993 and 2008 (Mostafa et al., 2009). This area has become a home for a large community of garbage collectors (El Zabbaleen) who occupied the top of the mountain hills. It had a residential density of more than 228 persons per square kilometre and was continuing to grow in density (Slum Development Fund, 2016).

Manshiet Nasser is one of the most dangerous slums in Egypt and its area reaches $7.2 \mathrm{Km}^{2}$ (GTZ-Egypt, 2016). Figure 3 shows the location of Manshiet Nasser in Cairo Governorate that is a mega slum of 800,000 to 1 million people (Scribol, 2010).

One of the most important problems in Manshiet Nasser is the failure of huge rock blocks from the high parts of the area on the residential buildings in the lower parts, as happened in El-Duwaiqain in 2008. Such an accident caused the death of more than one hundred people after one of the huge rocks collapsed on their homes (Slum Development Fund, 2016). 
Fig. 3. Location of Manshiet Nasser in Cairo Governorate

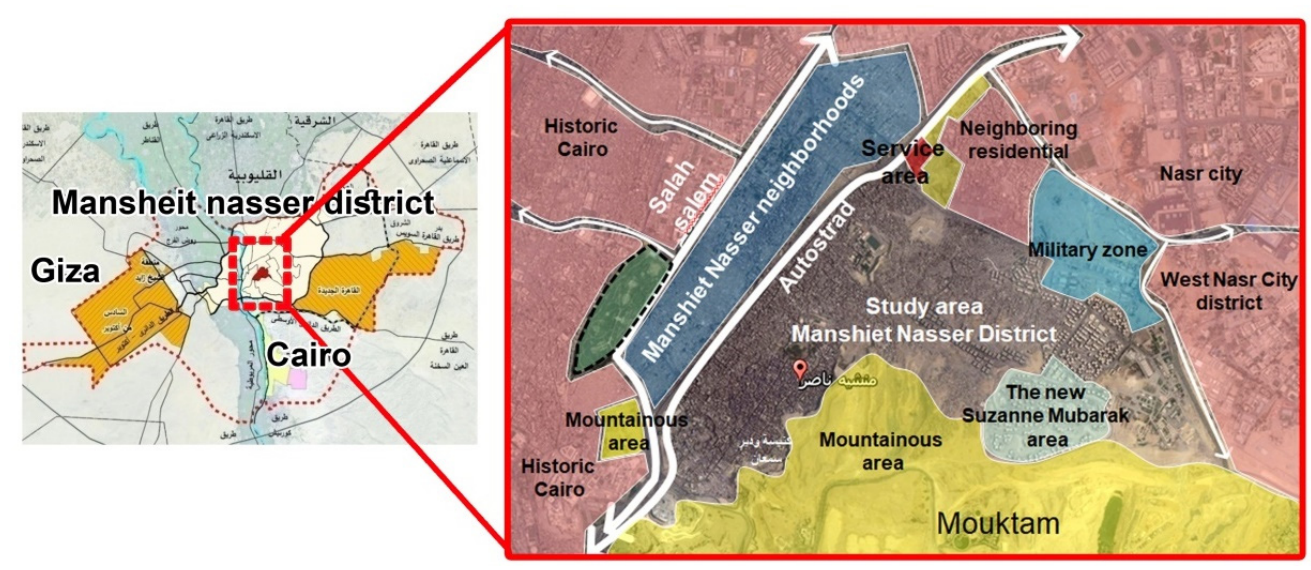

Manshiet Nasser is one of the most prone to rock failure areas in Egypt, where the rocky edge of Mount Mokattam has fallen more than once, as in 1993 and 2008, when the mountain of Mokattam collapsed on the slum residential area below the mountain. This occurred due to the following factors:

The edge of the mountain had several cracks, which increased by the earthquake of magnitude 5.6 Richter in October 1992 (Slum Development Fund, 2016). The NW trend was considered as the major active trend in Egypt. Such records showed that the area was vulnerable to seismic activity that might reach 4-5 on the Richter scale.

Most of stones were cut with limestone filled with caves and cracks. Their size increased when exposed to water, pressed on the edge rocks, and led to failure.

In 1993, the rainfall coincided with the edge of the mountain, causing the water to break into the cracks and reach the friable soil forming a viscous surface that led to rock failure.

There are buildings built on the edge of the mountain causing additional stresses that made the mountain's edge fall.

The non-technical implementation of the sewage network has led to leakage of water into the moun- tain's surface; in addition, it reached the festering soil inside the mountain.

The presence of quarries near the scene using explosives (dynamic loads) affected the balance of the mountain as well as the use of heavy equipment in the drilling by the construction companies (Ministry of Petroleum, 2009).

Rock failure triggers are used as independent variables to prepare a map of the probability of rockfall. A digital elevation model (DEM) is created to extract variables that are being used in this study such as slope angle and slope direction.

The used methodology to calculate and assess the risk of rock failure

A GIS-based (spatial) multi-criteria evaluation (SMCE) analysis was used in this study to combine the information from several criteria (factors) to form a single index of evaluation. Based on the available data, the landslide triggering factors were identified, so the rock failure susceptibility index (RSI) map can be produced (Effat and Hegazy, 2014).

Figure 4 shows the proposed methodology made by the authors to calculate and assess the risk of rock failure. It was developed by reviewing previous risk assessment methodologies referred to in the following research (Fell et al., 2005; AGS, 2002; Roslee et al., 2017). 
Fig. 4. The proposed methodology made by the authors to calculate and assess the risk of rock failure

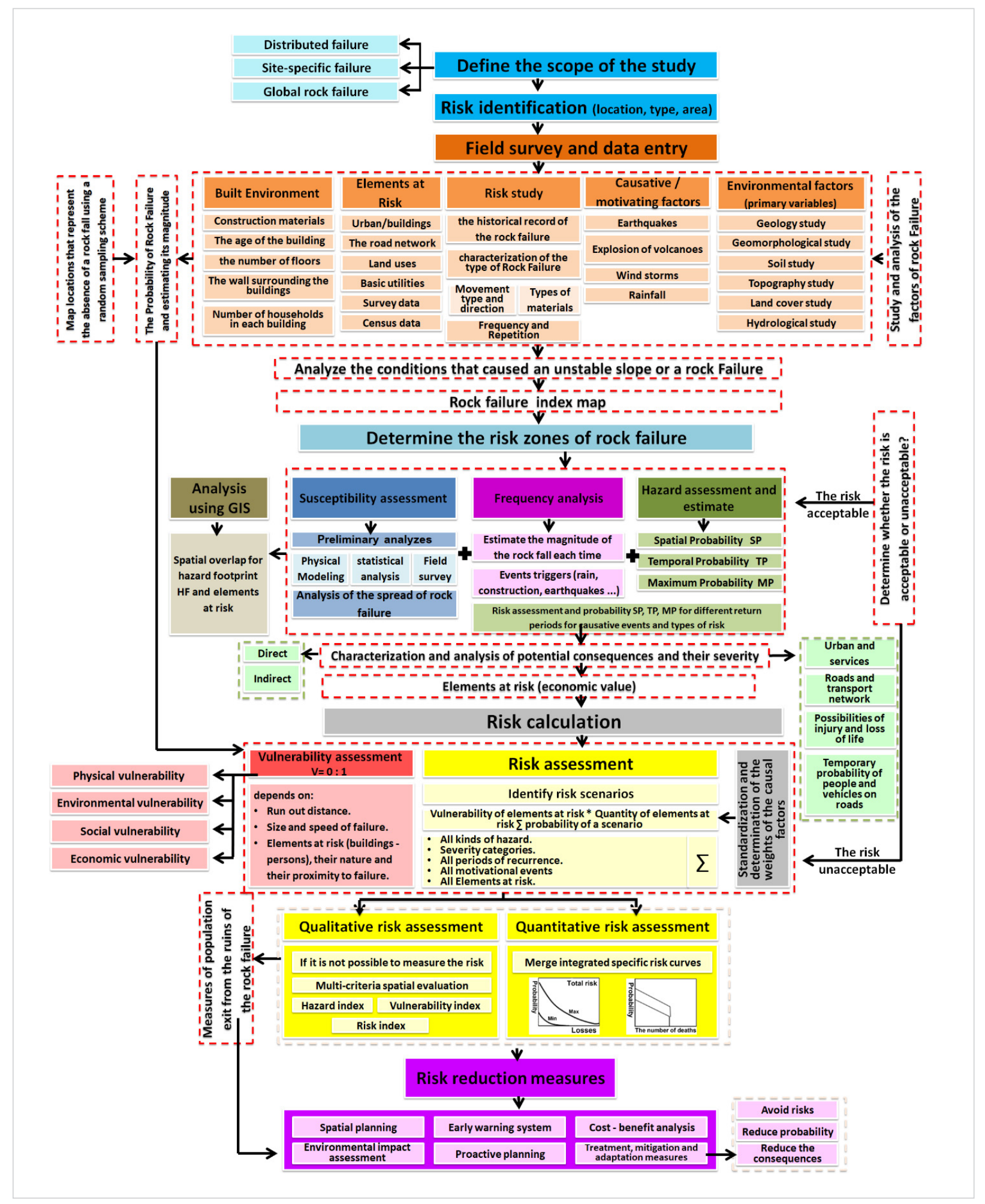




\section{Hazard assessment and estimation $(H)$}

There is a common difficulty encountered in every multi-criteria analysis, which is the number of factors to be considered (Ladas et al., 2007). The following factors were selected to assess and calculate the severity of rock failure hazard $(\mathrm{H})$ in the study area because of being a motivation and a cause for this occurrence. These factors vary from region to region and from risk to another, so the measurement must be standardised. Their relative weights have been determined by the previous equations. Table 4 shows hazard factors and their weights where the value of each category was changed to their relative weight in order to standardise all factors to facilitate the application of the general formula for risk assessment.

Table 4. Standardisation of hazard factors

\begin{tabular}{|c|c|c|c|c|c|c|c|}
\hline & $\begin{array}{c}\text { Hazard elements } \\
\text { HE }\end{array}$ & Rank & $\begin{array}{l}\text { Weight } \\
\text { of } \mathrm{HE}\end{array}$ & Categories & Rank & Weight & $\begin{array}{c}\text { Weight of category * } \\
\text { weight of HE }\end{array}$ \\
\hline \multirow{6}{*}{1} & \multirow{6}{*}{ Geology } & \multirow{6}{*}{13} & \multirow{6}{*}{1} & The Mokattam geology formation & 6 & 1.000 & 1.000 \\
\hline & & & & The Maadi geology formation & 5 & 0.833 & 0.833 \\
\hline & & & & Deposits of the valleys & 4 & 0.667 & 0.667 \\
\hline & & & & Giza geology formation & 3 & 0.500 & 0.500 \\
\hline & & & & The Red Mountain geology formation & 2 & 0.333 & 0.333 \\
\hline & & & & Modern deposits & 1 & 0.167 & 0.167 \\
\hline \multirow{7}{*}{2} & \multirow{7}{*}{ Slope } & \multirow{7}{*}{12} & \multirow{7}{*}{0.92} & $0-4$ degrees & 1 & 0.140 & 0.131 \\
\hline & & & & 4-8 degrees & 2 & 0.290 & 0.263 \\
\hline & & & & 8-10 degrees & 3 & 0.430 & 0.394 \\
\hline & & & & 10-14 degrees & 4 & 0.570 & 0.526 \\
\hline & & & & 14-20 degrees & 5 & 0.710 & 0.657 \\
\hline & & & & 20-30 degrees & 6 & 0.860 & 0.789 \\
\hline & & & & 30-45 degrees & 7 & 1.000 & 0.920 \\
\hline \multirow{2}{*}{3} & \multirow{2}{*}{$\begin{array}{l}\text { Previous rock } \\
\text { failure }\end{array}$} & \multirow{2}{*}{11} & \multirow{2}{*}{0.85} & Exist & 2 & 1.000 & 0.850 \\
\hline & & & & None & 1 & 0.500 & 0.425 \\
\hline \multirow{3}{*}{4} & \multirow{3}{*}{ Land cover } & \multirow{3}{*}{10} & \multirow{3}{*}{0.77} & Built areas & 2 & 0.667 & 0.513 \\
\hline & & & & Cultivated areas & 1 & 0.333 & 0.257 \\
\hline & & & & Desert-mountainous lands & 3 & 1.000 & 0.770 \\
\hline \multirow{8}{*}{5} & \multirow{8}{*}{ Topography } & \multirow{8}{*}{9} & \multirow{8}{*}{0.69} & $11-45 m$ & 1 & 0.130 & 0.086 \\
\hline & & & & $46-65 \mathrm{~m}$ & 2 & 0.250 & 0.173 \\
\hline & & & & $66-86 \mathrm{~m}$ & 3 & 0.380 & 0.259 \\
\hline & & & & $87-110 \mathrm{~m}$ & 4 & 0.500 & 0.345 \\
\hline & & & & $120-140 \mathrm{~m}$ & 5 & 0.630 & 0.431 \\
\hline & & & & $150-160 \mathrm{~m}$ & 6 & 0.750 & 0.518 \\
\hline & & & & $170-190 \mathrm{~m}$ & 7 & 0.880 & 0.604 \\
\hline & & & & $200-220 \mathrm{~m}$ & 8 & 1.000 & 0.690 \\
\hline
\end{tabular}




\begin{tabular}{|c|c|c|c|c|c|c|c|}
\hline & $\begin{array}{l}\text { Hazard elements } \\
\text { HE }\end{array}$ & Rank & $\begin{array}{l}\text { Weight } \\
\text { of } \mathrm{HE}\end{array}$ & Categories & Rank & Weight & $\begin{array}{l}\text { Weight of category * } \\
\text { weight of HE }\end{array}$ \\
\hline \multirow{2}{*}{6} & \multirow{2}{*}{ Steep rock edges } & \multirow{2}{*}{8} & \multirow{2}{*}{0.62} & Areas below mountain slopes & 2 & 1.000 & 0.620 \\
\hline & & & & Areas above mountain slopes & 1 & 0.500 & 0.310 \\
\hline \multirow{5}{*}{7} & \multirow{5}{*}{$\begin{array}{l}\text { Proximity } \\
\text { to drainage } \\
\text { systems }\end{array}$} & \multirow{5}{*}{7} & \multirow{5}{*}{0.54} & Less than $50 \mathrm{~m}$ & 5 & 1.000 & 0.540 \\
\hline & & & & From 50-100 m & 4 & 0.800 & 0.432 \\
\hline & & & & From $100-150 \mathrm{~m}$ & 3 & 0.600 & 0.324 \\
\hline & & & & From 150-200 m & 2 & 0.400 & 0.216 \\
\hline & & & & More than $200 \mathrm{~m}$ & 1 & 0.200 & 0.108 \\
\hline \multirow{3}{*}{8} & \multirow{3}{*}{$\begin{array}{l}\text { Distance from } \\
\quad \text { faults }\end{array}$} & \multirow{3}{*}{6} & \multirow{3}{*}{0.46} & Less than $50 \mathrm{~m}$ & 3 & 1.000 & 0.460 \\
\hline & & & & From 50-100 m & 2 & 0.670 & 0.307 \\
\hline & & & & more than $100 \mathrm{~m}$ & 1 & 0.330 & 0.153 \\
\hline \multirow{7}{*}{9} & \multirow{7}{*}{$\begin{array}{l}\text { Stream density } \\
\qquad(\mathrm{kg} / \mathrm{m} 3)\end{array}$} & \multirow{7}{*}{5} & \multirow{7}{*}{0.38} & $0-4 \mathrm{~kg} / \mathrm{m} 3$ & 1 & 0.140 & 0.054 \\
\hline & & & & $4-7 \mathrm{~kg} / \mathrm{m} 3$ & 2 & 0.290 & 0.109 \\
\hline & & & & $7-12 \mathrm{~kg} / \mathrm{m} 3$ & 3 & 0.430 & 0.163 \\
\hline & & & & $12-15 \mathrm{~kg} / \mathrm{m} 3$ & 4 & 0.570 & 0.217 \\
\hline & & & & $15-19$ kg / m3 & 5 & 0.710 & 0.271 \\
\hline & & & & $19-22 \mathrm{~kg} / \mathrm{m} 3$ & 6 & 0.860 & 0.326 \\
\hline & & & & $22-25 \mathrm{~kg} / \mathrm{m} 3$ & 7 & 1.000 & 0.380 \\
\hline 10 & Torrents & 4 & 0.04 & Areas located in the path of the torrent & 1 & 1.000 & 0.040 \\
\hline \multirow{3}{*}{11} & \multirow{3}{*}{$\begin{array}{c}\text { Terrain } \\
\text { roughness index }\end{array}$} & \multirow{3}{*}{3} & \multirow{3}{*}{0.03} & Easy & 1 & 0.330 & 0.010 \\
\hline & & & & Rugged & 2 & 0.670 & 0.020 \\
\hline & & & & Very rugged & 3 & 1.000 & 0.030 \\
\hline \multirow{8}{*}{12} & \multirow{8}{*}{ Slope direction } & \multirow{8}{*}{2} & \multirow{8}{*}{0.02} & North & 1 & 0.130 & 0.003 \\
\hline & & & & North East & 2 & 0.250 & 0.005 \\
\hline & & & & North West & 3 & 0.380 & 0.008 \\
\hline & & & & West & 4 & 0.500 & 0.010 \\
\hline & & & & South East & 5 & 0.630 & 0.013 \\
\hline & & & & East & 6 & 0.750 & 0.015 \\
\hline & & & & South West & 7 & 0.880 & 0.018 \\
\hline & & & & South & 8 & 1.000 & 0.020 \\
\hline \multirow{3}{*}{13} & \multirow{3}{*}{$\begin{array}{l}\text { Curvature of the } \\
\text { slope }\end{array}$} & \multirow{3}{*}{1} & \multirow{3}{*}{0.01} & concave & 3 & 0.500 & 0.005 \\
\hline & & & & flat & 2 & 0.333 & 0.003 \\
\hline & & & & convex & 1 & 0.167 & 0.002 \\
\hline
\end{tabular}




\section{Analysis of hazard factors $(H)$}

1 Slope. The slope angle is directly related to rock failure. It is frequently used in preparing susceptibility maps (Lerici et al., 2002). The higher the slope angle value, the steeper the terrain. The slope is one of the most important factors affecting the stability of slopes in the area of Manshiet Nasser, where it ranges from 3 to 45 degrees and the steepest area is El-Zarayeb and El-Masaken areas as shown in Figure 5. The slope angle values were derived from the SRTM digital elevation model using the spatial analyst Arc GIS10.1.

2 Previous Rock Failure. Figure 6 shows the locations and dates of major previous rock failure incidents and their locations, which are more susceptible to the occurrence of rock failure again.

3 Geology. Landslides are greatly controlled by the lithology properties of the land surface. Since different lithological units have different landslide susceptibility values, they are very important in providing data for susceptibility mapping (Pourghasemi, 2012). The lithology in Manshiet Nasser consists of clay, sandy clay, Nile deposits, Wadi deposits, sandstone, sand gravel siltstone, and clay stone in addition to vast zones of limestone and chalky limestone as shown in Figure 7. Table 5 shows the geology formation of Manshiet Nasser.

4 Topography. The topography is a very important factor because it is controlled by several geologic and geomorphological processes (Ayalew et al., 2004). The topography of Manshiet Nasser ranges from 11 to 220 meters as shown in Figure 8. The areas on El Mouktam Mountain, which are El-Duwaiqa and Wadi Pharaon, are the most elevated and the most vulnerable to rock failures. The SRTM digital elevation model was used in this study.

5 Distance from a drainage system. Figure 9 shows the drainage systems of the study area, where the non-technical implementation of the sewage network leads to leakage of water into the mountain's surface and thus reaches the festering soil inside the mountain.

6 Steep rock edge. Figure 10 shows the areas located below and above the mountain edges, which have not considered the application of the allowed safety
Table 5. The geology formation of Manshiet Nasser

\begin{tabular}{|l|l}
\hline $\begin{array}{l}\text { Deposits of the } \\
\text { valleys }\end{array}$ & $\begin{array}{l}\text { It is the Holocene deposits, which are } \\
\text { formations of gravel, sand, limestone } \\
\text { fragments and alluvial deposits in the } \\
\text { valleys (Abd Elhameed, 2004). }\end{array}$ \\
\hline Red Mountain & $\begin{array}{l}\text { It is located within the formations of } \\
\text { Oligocene, occupies 9.1\% of the total } \\
\text { surface area of the plateau, and con- } \\
\text { tains gravel, coarse sand, soft coher- } \\
\text { ent bright colours, predominantly red, } \\
\text { in the areas around the faults. }\end{array}$ \\
\hline Maadi geology & $\begin{array}{l}\text { It is a composition of the Eocene era. } \\
\text { It is characterised by the presence of } \\
\text { brown clay that is easy to divide. The } \\
\text { clay overlaps with limestone that is } \\
\text { high in its content of lime and sand. }\end{array}$ \\
\hline Limestone & $\begin{array}{l}\text { Middle Eocene formations are known } \\
\text { as Mouktam formations and are char- } \\
\text { acterised by an increase in the propor- } \\
\text { tion of gypsum in limestone rocks that } \\
\text { raises their ability to create caves filled } \\
\text { with clay, the layers of which may leak } \\
\text { water when exposed. }\end{array}$ \\
\hline formation & $\begin{array}{l}\text { There are many types of limestone in } \\
\text { the plateau of Mouktam, in terms of } \\
\text { type, thickness, and features. It is con- } \\
\text { centrated on the western edges east } \\
\text { to the Citadel of Mohamed Ali along } \\
\text { Salah Salem road and in the area of } \\
\text { El-Duwaiqa, characterised by yel- } \\
\text { leys and chalky limestone (Abd Elha- } \\
\text { lowish-white colour and divided into } \\
\text { mand-limestone, clay-limestone, dolo- }\end{array}$ \\
\hline litic limestone, clay-limestone-Mar-
\end{tabular}

distance. The safety distance is equal to the length of the rocky slope, making it one of the most dangerous areas for the population and urban areas.

According to the analysis of hazard factors, Figure 11 shows hazard severity categories, where the highest hazard severity is the highest elevation, located nearby the steep mountain edges (Mouktam Mountain) and fault zones. Most of it is mountainous terrain with a geological formation of limestone permeating with clay located on previous rock failure zones. However, these indicators should be compared with the vulnerability analysis to assess risk accurately. 
Fig. 5. The slope map of the study area

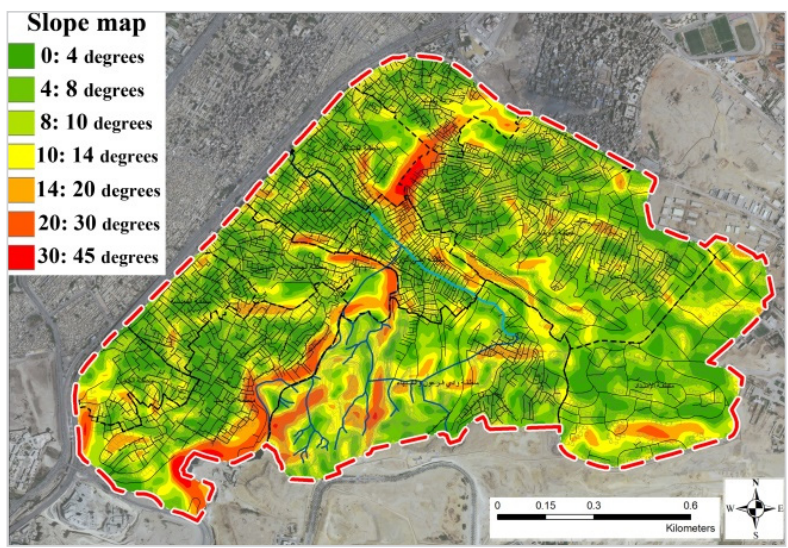

Fig. 7. The geology map of the study area

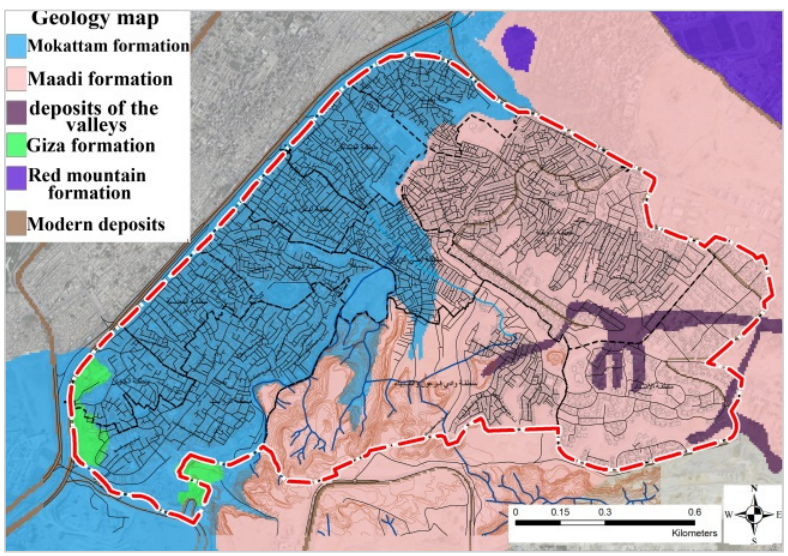

Fig. 9. Distance from drainage systems

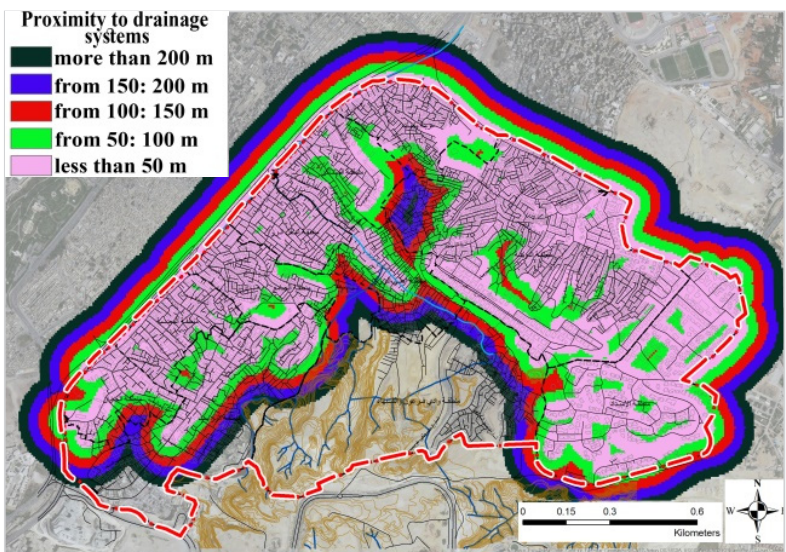

Fig. 6. Previous rock failure in the study area

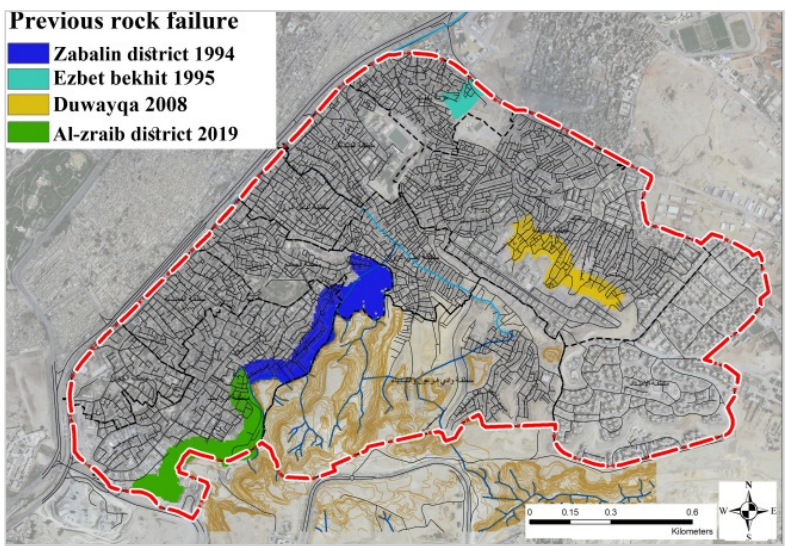

Fig. 8. The topography map of the study area

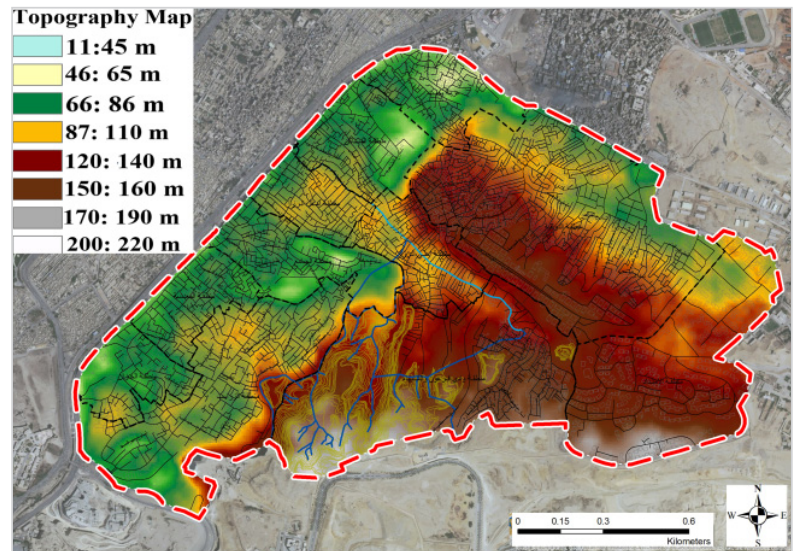

Fig. 10. Steep rock edges of the study are

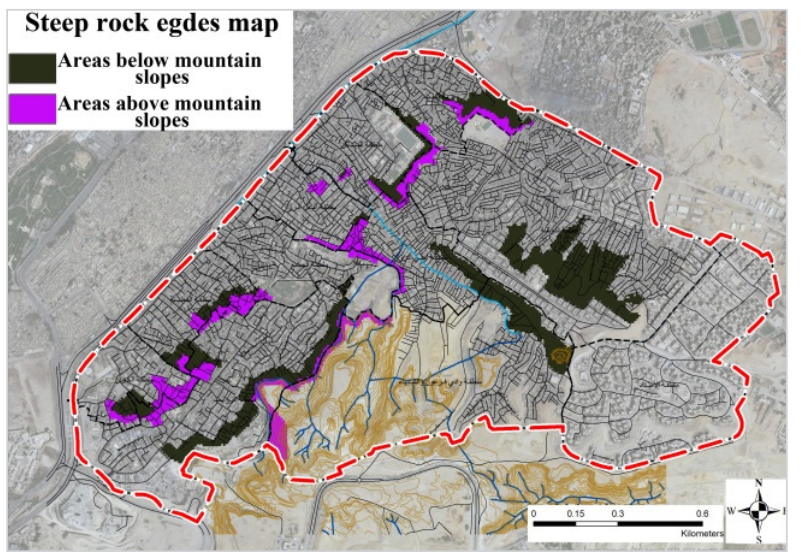


Fig. 11. The hazard severity assessment map of the study area and its categories

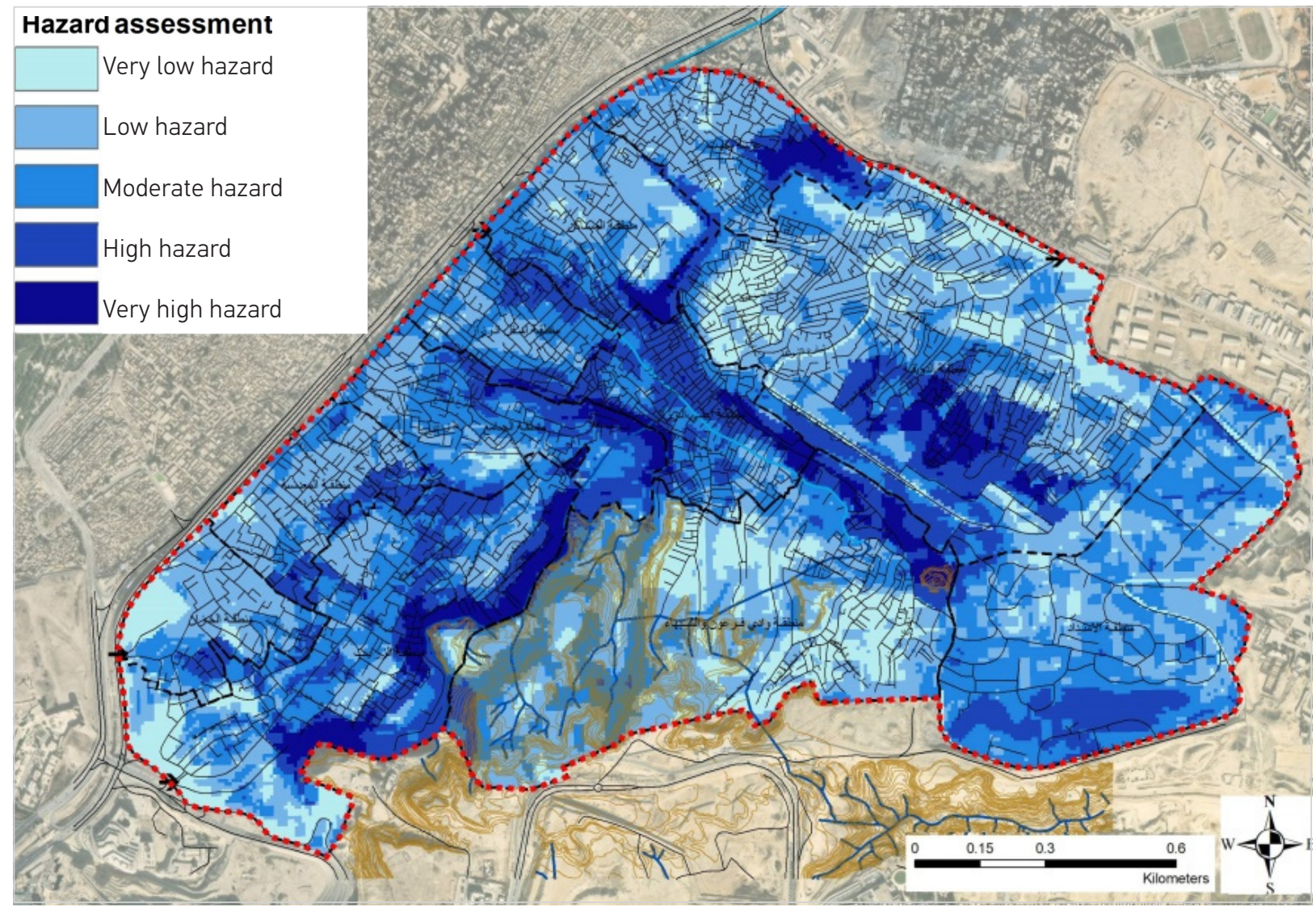

\section{Vulnerability assessment}

The elements' value at risk was estimated to assess and calculate the vulnerability of urban areas and population. As for urban areas, the vulnerability of land uses, building age, number of floors, building conditions, construction materials, basic facilities, and road networks were studied. However, as for population, the vulnerability in each building and the population density in the study area were studied. Their measurement was standardised to conclude the vulnerability index map of the elements at risk.

Table 6 shows the vulnerability factors and their weight, where the value of each category was changed to their relative weight in order to standardise all factors to facilitate the application of the general formula for risk assessment.

\section{Analysis of vulnerability factors( $V$ )}

1 Population density. El-Masaken area is considered one of the most densely populated areas, ranging from 500 to 750 person/acre, followed by Al-Zaraib area. The population density in El-Duwaiqa area and the extension areas is reduced as shown in Figure 12.

2 Land uses. When the vulnerable populations are at risk, the locations of buildings should be identified, such as kindergartens, hospitals, nursing homes, schools and their distances to services (civil defence and police) as shown in Figure 13. Meanwhile, the building used for activities in which the population has longer hours during the day is the most vulnerable.

3 Construction materials and type. The buildings with a concrete structure, which represent $62 \%$ of the area, are the least vulnerable to rock failure as shown in Figure 14. 
Table 6. Standardisation of vulnerability (V) factors

\begin{tabular}{|c|c|c|c|c|c|c|c|}
\hline & Elements of $\mathrm{V}$ & Rank & Weight & Categories & Rank & Weight & $\begin{array}{l}\text { Weight of category * } \\
\text { weight of } V \text { element }\end{array}$ \\
\hline \multirow{4}{*}{1} & \multirow{4}{*}{$\begin{array}{l}\text { Population } \\
\text { density }\end{array}$} & \multirow{4}{*}{10} & \multirow{4}{*}{1} & 100-300 personlacre & 1 & 0.25 & 0.25 \\
\hline & & & & $300-400$ personlacre & 2 & 0.5 & 0.5 \\
\hline & & & & 400-500 personlacre & 3 & 0.75 & 0.75 \\
\hline & & & & $500-750$ personlacre & 4 & 1 & 1 \\
\hline \multirow{9}{*}{2} & \multirow{9}{*}{ Land use } & \multirow{9}{*}{9} & \multirow{9}{*}{0.9} & Groves, dumps garbage, space, squares \& sheds & 1 & 0.11 & 0.1 \\
\hline & & & & Facilities & 2 & 0.22 & 0.2 \\
\hline & & & & Security services \& general services & 3 & 0.33 & 0.3 \\
\hline & & & & Entertainment, educational, cultural \& social & 4 & 0.44 & 0.4 \\
\hline & & & & Administrative & 5 & 0.56 & 0.5 \\
\hline & & & & Commercial \& crafts & 6 & 0.67 & 0.6 \\
\hline & & & & Healthy, sport \& religious & 7 & 0.78 & 0.7 \\
\hline & & & & $\begin{array}{l}\text { Residential commercial, residential crafts \& } \\
\text { residential religious }\end{array}$ & 8 & 0.89 & 0.8 \\
\hline & & & & Residential & 9 & 1 & 0.9 \\
\hline \multirow{10}{*}{3} & \multirow{10}{*}{$\begin{array}{c}\text { Construction } \\
\text { materials } \\
\text { and type }\end{array}$} & \multirow{10}{*}{8} & \multirow{10}{*}{0.8} & Concrete structure & 1 & 0.1 & 0.08 \\
\hline & & & & Carrier walls \& concrete roof & 2 & 0.2 & 0.16 \\
\hline & & & & Carrier walls \& light ceiling & 3 & 0.3 & 0.24 \\
\hline & & & & Brick covered & 4 & 0.4 & 0.32 \\
\hline & & & & Brick without roof & 5 & 0.5 & 0.4 \\
\hline & & & & Clay covered & 6 & 0.6 & 0.48 \\
\hline & & & & Tin nest & 7 & 0.7 & 0.56 \\
\hline & & & & Wooden roofing & 8 & 0.8 & 0.64 \\
\hline & & & & Wooden structure without roof & 9 & 0.9 & 0.72 \\
\hline & & & & Weak structure & 10 & 1 & 0.8 \\
\hline \multirow{4}{*}{4} & \multirow{4}{*}{$\begin{array}{l}\text { Building } \\
\text { condition }\end{array}$} & \multirow{4}{*}{7} & \multirow{4}{*}{0.7} & Good & 1 & 0.25 & 0.18 \\
\hline & & & & Medium & 2 & 0.5 & 0.35 \\
\hline & & & & Bad & 3 & 0.75 & 0.53 \\
\hline & & & & Deteriorated & 4 & 1 & 0.7 \\
\hline
\end{tabular}




\begin{tabular}{|c|c|c|c|c|c|c|c|}
\hline & Elements of $\mathrm{V}$ & Rank & Weight & Categories & Rank & Weight & $\begin{array}{l}\text { Weight of category * } \\
\text { weight of } V \text { element }\end{array}$ \\
\hline \multirow{5}{*}{5} & \multirow{5}{*}{$\begin{array}{l}\text { The age of } \\
\text { the building }\end{array}$} & \multirow{5}{*}{6} & \multirow{5}{*}{0.6} & The first period 1966 & 5 & 1 & 0.6 \\
\hline & & & & The second period 1966-1977 & 4 & 0.8 & 0.48 \\
\hline & & & & The third period 1977-1996 & 3 & 0.6 & 0.36 \\
\hline & & & & The fourth period 1996-2011 & 2 & 0.4 & 0.24 \\
\hline & & & & The fifth period from 2011 to now & 1 & 0.2 & 0.12 \\
\hline \multirow{3}{*}{6} & \multirow{3}{*}{$\begin{array}{l}\text { Building } \\
\text { heights }\end{array}$} & \multirow{3}{*}{5} & \multirow{3}{*}{0.5} & Less than 2 floors & 1 & 0.33 & 0.17 \\
\hline & & & & From 3-4 floors & 2 & 0.67 & 0.33 \\
\hline & & & & More than 5 floors & 3 & 1 & 0.5 \\
\hline \multirow{2}{*}{7} & \multirow{2}{*}{$\begin{array}{c}\text { Road } \\
\text { network } \\
\text { condition }\end{array}$} & \multirow{2}{*}{4} & \multirow{2}{*}{0.4} & Paved roads & 2 & 1 & 0.4 \\
\hline & & & & Dirt roads un paved & 1 & 0.5 & 0.2 \\
\hline \multirow{2}{*}{8} & \multirow{2}{*}{$\begin{array}{c}\text { Water } \\
\text { networks }\end{array}$} & \multirow{2}{*}{3} & \multirow{2}{*}{0.3} & Connected & 2 & 1 & 0.3 \\
\hline & & & & Disconnected & 1 & 0.5 & 0.15 \\
\hline \multirow{2}{*}{9} & \multirow{2}{*}{$\begin{array}{l}\text { Drainage } \\
\text { systems }\end{array}$} & \multirow{2}{*}{2} & \multirow{2}{*}{0.2} & Connected to an integrated network & 2 & 1 & 0.2 \\
\hline & & & & Connected to a shallow network & 1 & 0.5 & 0.1 \\
\hline \multirow{2}{*}{10} & \multirow{2}{*}{$\begin{array}{l}\text { Electricity } \\
\text { networks }\end{array}$} & \multirow{2}{*}{1} & \multirow{2}{*}{0.1} & Connected & 2 & 1 & 0.1 \\
\hline & & & & Disconnected & 1 & 0.5 & 0.05 \\
\hline
\end{tabular}

4 Building conditions. The buildings with bad conditions, which represent $14.88 \%$ of the area, are the most vulnerable to rock failure as shown in Figure 15.

5 Building heights. The tallest buildings represent the highest vulnerability, where more than 5 floors are constructed as shown in Figure 16.

6 The age of buildings. The study of the age of buildings is important to determine their vulnerability to rock failure, as old buildings are more vulnerable compared with modern buildings; the term modern refers to the period from 2011 until now as shown in Figure 17.
The following vulnerability map as shown in Figure 18 shows the highest vulnerability zones that are affected by the risk of rock failure. These zones are densely populated and contain degraded poor houses that are constructed by weak building materials such as mud and wood without ceiling. In addition, they mainly serve vital activities, whether economic or social, while they are located on roads with a poor dirty status.

Moreover, the map shows that the northern area of Manshiet Nasser (study area) is the most vulnerable, because of the high population density and the status of houses that are degraded, poor and constructed by weak building materials such as mud and wood without ceilings. 
Fig. 12. Population density of the study area

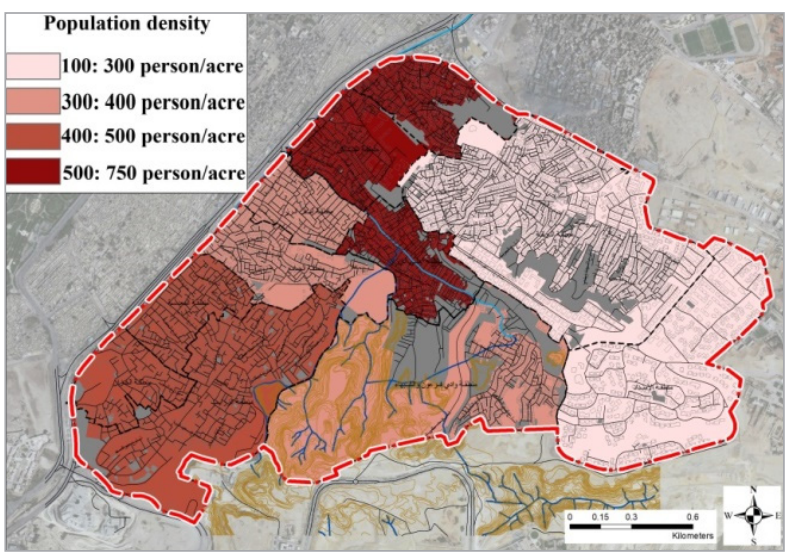

Fig. 14. Construction materials and type

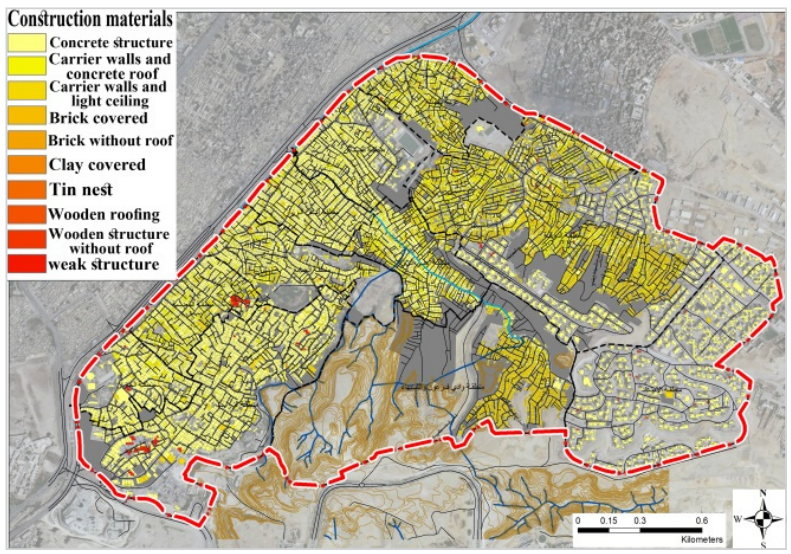

Fig. 16. Building heights of the study area

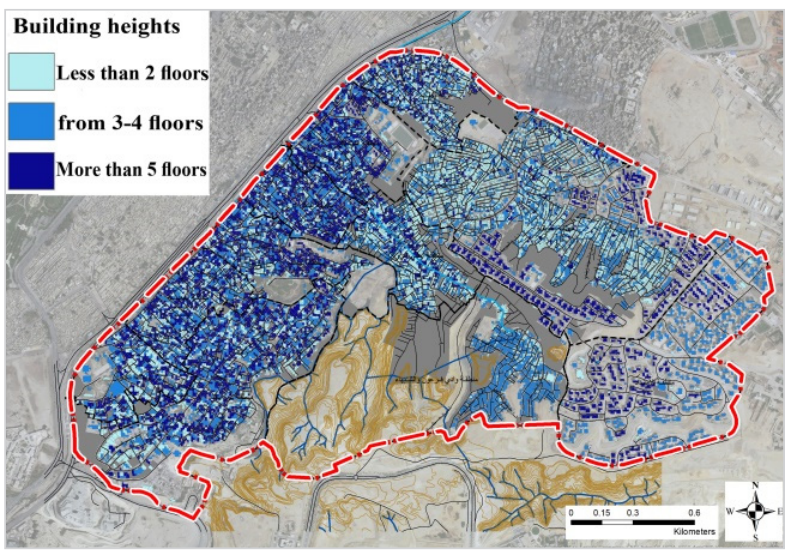

Fig. 13. Land uses of the study area

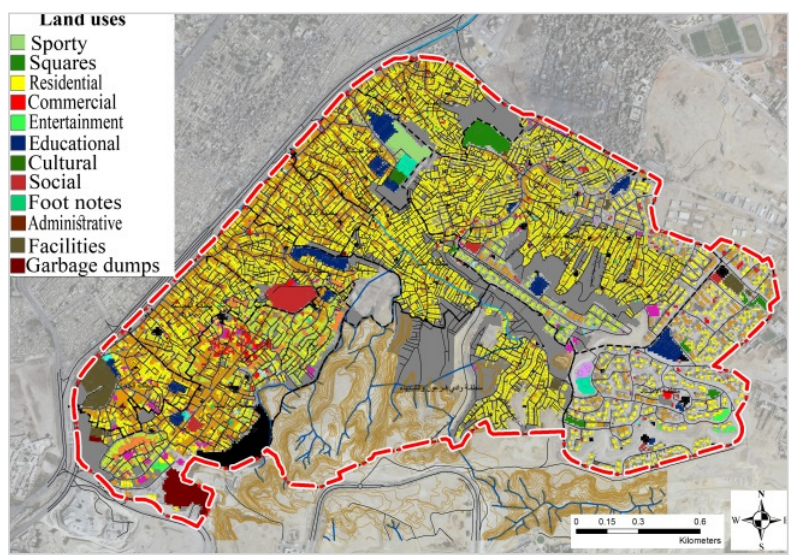

Fig. 15. The building condition of the study area

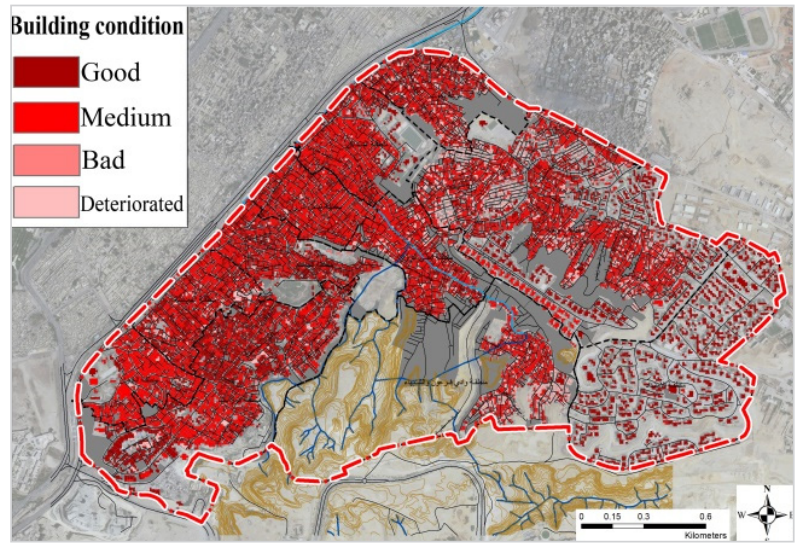

Fig. 17. The age of the buildings in the study area

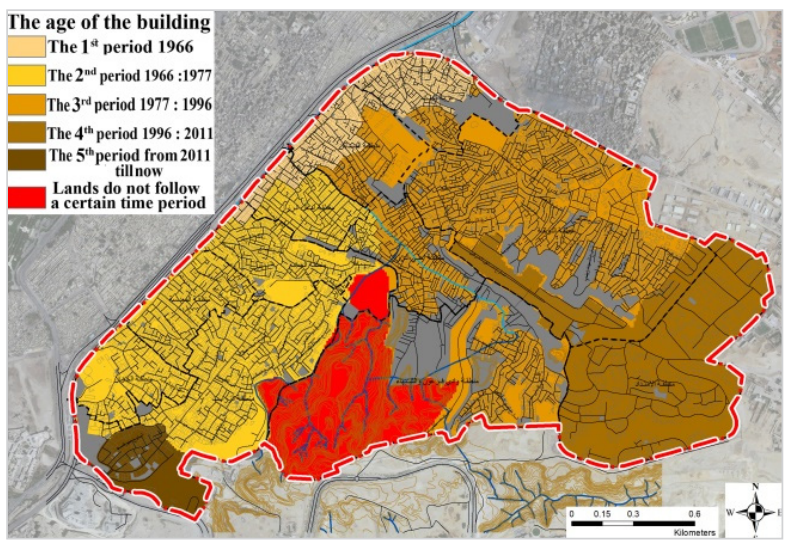


Fig. 18. The vulnerability assessment map

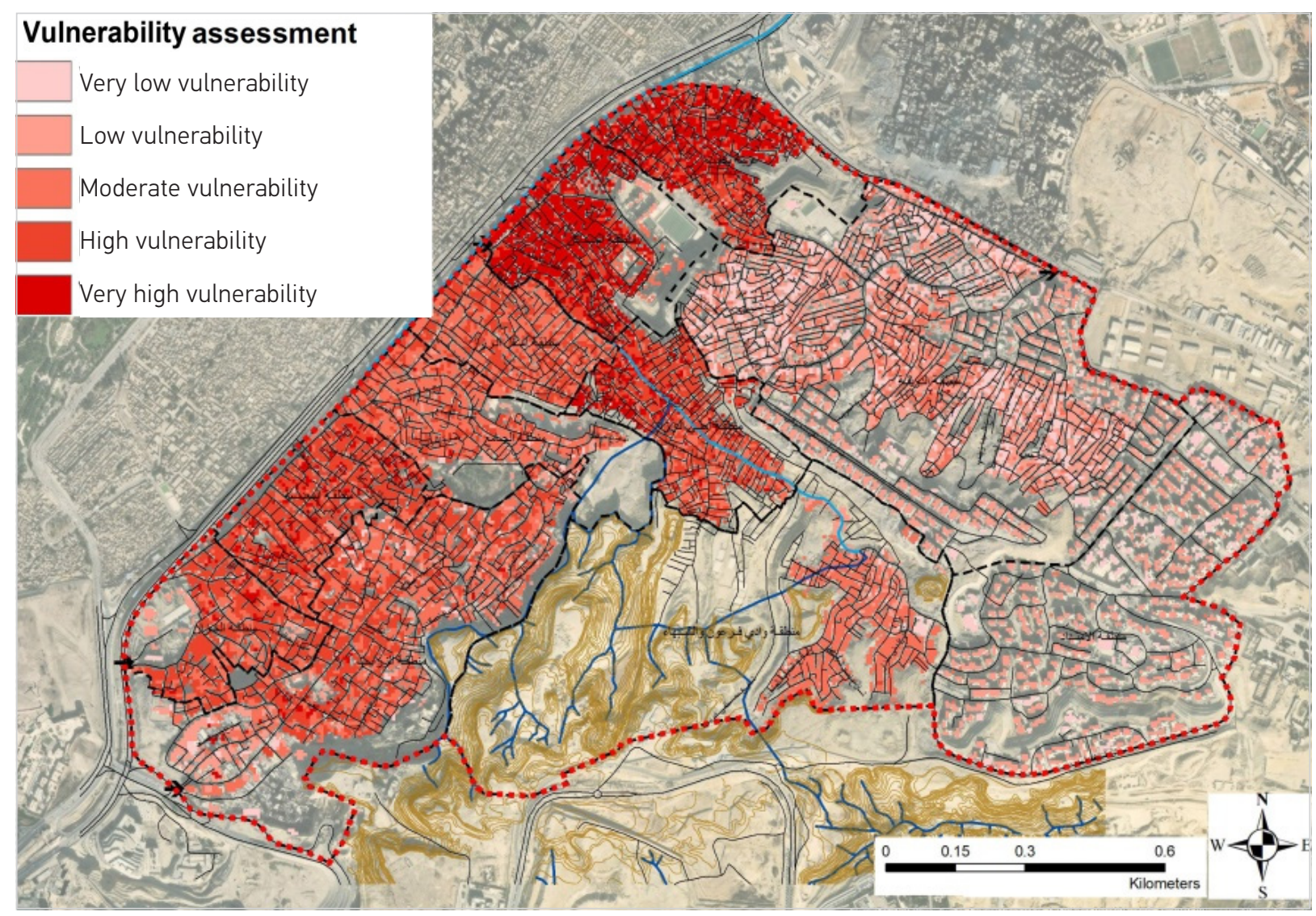

\section{Results and Discussion}

The multivariate statistics were used according to the methodology that links the occurrence of rock collapse in a given cell (pixel) with the occurrence of several factors in the same cell. The area map was presented as cells $(10 \mathrm{~m} * 10 \mathrm{~m})$. Each cell had a value of $\mathrm{H}$ and $\mathrm{V}$, with a total of 45,723 cells/ pixels. The general risk assessment equation was applied by multiplying the vulnerability $(V)$ to the severity of hazard $(H)$ using the Map Algebra tool in the GIS programme to assess the final risk. The weighted linear combination model resulted in a rock failure susceptibility index map RSI demonstrated in figure 19, where it shows that the most risky areas are in the eastern border of El-Razzaz area and also the southern border of El-Zarayeb area, which are the edges of Mount Mouktam, while the least risky areas are south of El-Duwaiqa and its extension area.
In case of the rockslide history map, a value is set for each cell equal to 1 , where the previous rock failure happened in this cell and 0 if no previous rock failure occurred in this cell. The maps of the triggers and causes of the rock failure were prepared by the GIS programme, which calculates the degree of hazard using the following factors: geology, slope direction, slope curvature, faults, stream density, terrain roughness index, proximity to drainage systems, historical record of previous slides, land cover, torrents accumulations paths, topography and slopes. They were standardised and their relative weights were determined by the previous equations, by unifying all factors on a numeric scale from 0 to 1 to facilitate their calculation as shown in Table 7 . The vulnerability maps were prepared. The vulnerability of the 
Fig. 19. The risk assessment map (final map)

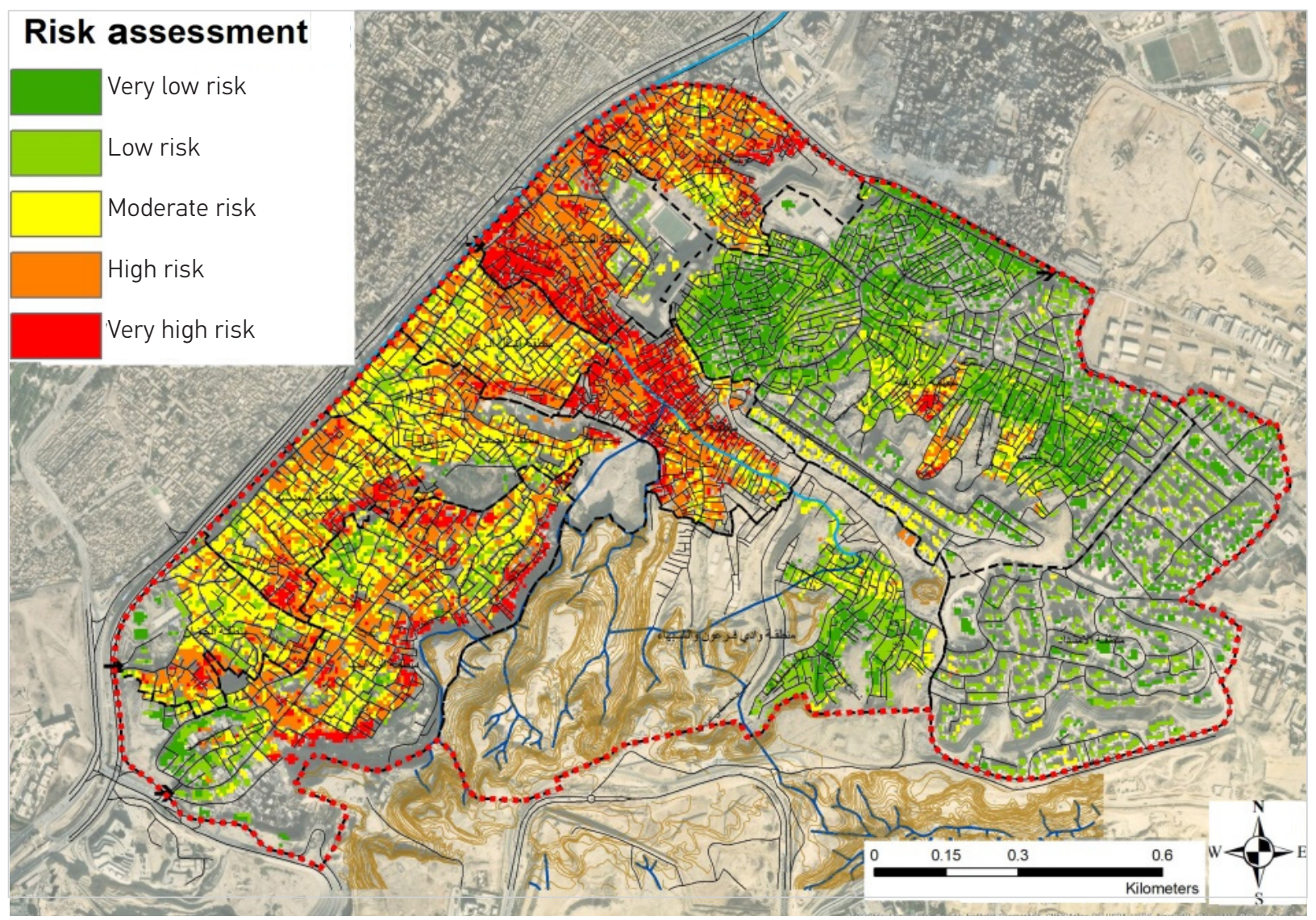

Table 7. The classification of the predicted risk value from the model

\begin{tabular}{c|c}
\hline Estimated value & Relative class \\
\hline $1.00-0.75$ & Very high \\
\hline $0.75-0.55$ & High \\
\hline $0.55-0.30$ & Moderate \\
\hline $0.30-0.10$ & Low \\
\hline $0.10-0.00$ & Very low \\
\hline
\end{tabular}

population and urban areas are measured according to land use, building age, number of floors, number of inhabitants in each building, basic facilities, building conditions, construction materials, and road network and its conditions. The measurement was standardised by a digital scale from 0 to 1 , and the final map of vulnerability was extracted.
A database was prepared using GIS to link the triggers of rock failure with the vulnerability of the elements at risk, in order to conclude the map of the rock failure hazard index in the study area and to know the consequences of assessing the risk of rock failure on land use, road network and population. This helps in land and risk management to develop mitigation, treatment and adaptation strategies. The application on the study area includes conducting a survey to determine the rock failure and its characteristics by analysing the aerial photographs and the field study, and a spatial correlation between rock failure and catalysts to develop recommendations for the settlement of land use in the region. The research proves that the use of such a model is an effective and cost-saving tool for mapping the rock failure risk assessment. It can identify rock failure subsidence in susceptible zones. It can also identify vulnerable locations of infrastructure that 
are exposed to such a risk. Measuring and building codes could, therefore, be applied at the early stages of planning; therefore, such maps are recommended prior to the zone and site selection phases.

\section{Conclusions}

Designing a risk assessment and a forecasting approach is important to promote the concept of sustainability in environmental risk management, because many countries do not have standard criteria for assessing the risk of rock failure. As a result, the risk assessment of rock failure is still evolving. A set of data must be available for each type of risk to start the risk assessment process, followed by standardising the weights of these criteria according to the researcher or decision makers' vision. The stage of calculating the risk and its impact on the urban areas

\section{References}

Abd Elhameed R. (2004) Mokattam Plateau, Study in Applied Geomorphology. Zagazig, Egypt: Master Thesis, Faculty of Arts, Department of Geography, Zagazig University. (accessed 15 November 2019).

Ahour M., Hataf N., and Azar E. (2019) A Mathematical Model Based on Artificial Neural Networksto Predict the Stability of Rock Slopes Using the GeneralizedHoek-Brown Failure Criterion. Geotech Geol Eng. available at: https://link.springer.com/ content/pdf/10.1007/s10706-019-01049-y.pdf. (accessed 15 February 2020), 2019.

Ayalew L., Yamagishi H. and Ugana N. (2004) Landslide susceptibility map-ping using GIS-based weighted linear combination, the case in Tsugawa area of Agano River. Japan: Niigata Prefecture. pp. 73-81. Available at: https://link.springer.com/article/10.1007/s10346-003-0006-9. (accessed 03 October 2019). https://doi.org/10.1007/s10346-003-0006-9

Azzam R., Arnhardt C. and Steeger T. (2010) Monitoring and early warning of slope instabilities and deformations by sensor fusion in self-organized wireless ad-hoc sensor networks. Germany: Department of Engineering Geology and Hydrogeology (LIH), RWTH Aachen University, J. SE Asian Appl. Geol., SepDec 2010, Vol. 2(3), pp. 163-169. available at: https://www.researchgate.net/publication/252068698_Monitoring_and_Early_Warning_of_Slope_Instabi. (accessed 03 October 2019). and population is necessary to calculate the economic value of the elements at risk. The risk assessment is a step in a larger process based on the results of the assessment, because it is the basis for planning and decision-making. There are many ways to calculate the risk and vulnerability methods that vary according to the type of risk and many other factors. Conducting more detailed studies based on this topic in the study area are further needed and must be encouraged more. The map of the final risk assessment of rock failure shows the areas most vulnerable to future rock failure. This helps population to avoid exposing to death and damage in urban areas. It is the basic map to be relied on when planning this area in the future. The proposed approach helps to analyse the factors causing the occurrence of rock slides in the area of Manshiet Nasser, so the risk severity index map is produced to show the factors of vulnerability and the inferring elements at risk and their vulnerability.

Bell R. and Glade T. (2004) Quantitative risk analysis for landslides - Examples from B'Ildudalur, NW-Iceland. Germany: Natural Hazards and Earth System Sciences, pp. 117-131. (accessed 20 December 2019). https://doi.org/10.5194/ nhess-4-117-2004

Costard S. (2008) Introduction to Risk Analysis and Risk Assessment. London: University of London. p. 44. Available at:https:// scholar.google.com.eg/scholar?q=Introduction+to+Risk+Analysis+And+Risk+Assessment\&hl=ar\&as_sd t=0\&as_vis=1\&oi=scholar. (accessed 15 January 2020).

Dai F., Lee C., Li J. and Xu, Z. (2001) Assessment of landslide susceptibility on the natural terrain of Lantau Island, Hong Kong. Springer-Verlag. p. 11. Available at: https://link.springer.com/article/10.1007/s002540000163. (accessed 03 October 2019).

Effat H. and Hegazy M. (2014) Mapping landslide susceptibility using satellite data and spatial multicriteria evaluation: The case of Helwan District, Cairo. Cairo. Egypt: Applied Geomatics. pp. 215-228. Available at: https://link.springer.com/article/10.1007/s12518-014-0137-9. (accessed 15 February 2020). https://doi.org/10.1007/s12518-014-0137-9

Fell R., Ho K., Lacasse S. and Lerio E. (2005) A framework for landslide Risk Assessment and Management. London: International Conference on Landslide Risk Management. p. 23. Available at: https://www.researchgate.net/publication/209803815_A_ 
framework_for_landslide_risk_assessment_and_management. (accessed 30 december 2019).

GTZ-Egypt, G. (2016) Participatory Development Programme Project Manshiet Nasser. Cairo: Ministry of Housing, Utilities and Urban Communities. p. 15. (Accessed 25 April 2019).

Guillard C. and Zezere J. (2012) Landslide susceptibility assessment and validation in the framework of municipal planning in Portugal: The case of Loures Municipality. Environmental Management. Volume 50, pp. 721-735. Available at: https://link. springer.com/article/10.1007/s00267-012-9921-7. (accessed 20 December 2019). https://doi.org/10.1007/s00267-012-9921-7

Hamza O., Vargas T., Boff F., Hussain Y. and Vollum K. (2019) Geohazard Assessment of Landslides in South Brazil: CaseStudy. Geotech Geol Eng. available at: https://link.springer. com/content/pdf/10.1007/s10706-019-01054-1.pdf (accessed 1 March 2020). https://doi.org/10.1007/s10706-019-01054-1

Hegazy I. (2016) Informalsettlement upgrading policies in Egypt: towards improvement in the upgrading process. Journal of Urbanism. available at: https://www.academia.edu/download/57602365/Informal_Settlements_final_15-8-2018.pdf. (accessed 16 February 2020).

Ministry of Petroleum (2009) Geological and engineering studies to assess the state of the slopes of the northern edge of the Mokattam plateau-Final Report of Phase I (Volume 1). Cairo: Ain-Shams University and General Authority for Mineral Resources. p. 123. (Accessed 15 April 2019).

Kanungo D. and Sarkar S. (2004) An Integrated Approach for Landslide Susceptibility Mapping Using Remote Sensing and GIS. India: Photogrammetric Engineering \& Remote Sensin. p. 10. Available at: https://pdfs.semanticscholar.org/44bf/ 3890ca92f1387d309aaa2b0b745f9c7bc612.pdf. (accessed 15 December 2019).

Khaled M., Abdel Rhman K. and Kattab M. (2008) Facing the Drilling and blasting difficulties at Helwan Quarry. Egypt: Int Soc Explos Eng G. pp. 1-13. Available at: https://www.ascom.com. eg/files/ISEE2008.pdf. (accessed 15 december 2019).

Ladas I., Mariolakos I. and Fountoulis I. (2007) Using GIS \& Multi criteria decision analysis in landslide susceptibility mapping: A case study in Messinia Prefecture Area, SW Peloponnesus. Greece, Athens: Bulletin ofthe Geological Society of Greece. Available at: https://www.researchgate.net/publication/325563875. (accessed 15 February 2020). https://doi. org/10.12681/bgsg. 17240

Lerici A., Perego S., Tellini C. and Vescovi P. (2002) A procedure for landslide susceptibility zonation by the conditional analysis method Geomorphology. pp. 349-364. Available at: https:// www.researchgate.net/publication/223 180096_A_procedure_for_landslide_susceptibility_zonation_by_the_condition- al_analysis_method. (accessed 15 december 2019). https:// doi.org/10.1016/S0169-555X(02)00079-X

Mostafa A., El Nahas F., Yousef M., Hefny A. and El Kady M. (2009) Geological and engineering studies in the case of the slopes of the northern edge of the Mokattam Plateau - Final Report of the first phase. Cairo: Mineral Resources Authority, Ministry of Petroleum. Available at: https://www.academia.edu/31481423/ Engineering_geology_of_Mokattam_city_and_vicinity_eastern_ Greater_Cairo_Egypt. (accessed 15 february 2020).

Murillo F. G., Mauro R., Francesca A., Fiorucci F. and Irasema A. (2017) Hazard and population vulnerability analysis: A step towards landslide risk assessment. Journal of Mountain Science 14(7), pp. 1241-1261. Available at: https://www.researchgate. net/publication/318185113_Hazard_and_population_vulnerability_analysis_a_step_towards_landslide_risk_assessment. (accessed 30 January 2020). https://doi.org/10.1007/s11629016-4179-9

Pareta K. and Kumar J. (2012) Landslide hazard zonation using Quantitative Methods in GIS. Int J Geospatial Eng Technol. pp. 1 : 9. Available at: https://www.researchgate.net/publication/325779809_Landslide_Hazard_Zonation_using_Quantitative_Methods_in_GIS (accessed 20 December 2019).

Papathoma Kohle M., Neuhauser B., Ratzinger K., Wenzel H. and Dominey-Howes (2007) Elements at risk as a framework for assessing the vulnerability of communities to landslides. Copernicus Publications on behalf of the European Geosciences Union. pages: 765-779. Available at: https://www. researchgate.net/publication/29629861_Elements_at_risk_ as_a_framework_for_assessing_the_vulnerability_of_communities_to_landslides. (accessed 15 August 2019). https:// doi.org/10.5194/nhess-7-765-2007

Pourghasemi H. R. (2012) Landslide hazard assessment using fuzzy logic,case study: a part of Haraz Watershed. Iran: M.Sc. Thesis, Tarbiat Modarres University International Campus. p. 92. Available at: https://link.springer.com/article/10.1007/ s11069-012-0217-2. (accessed 15 August 2019).

Rezaee Z., Fisher P. and Balzter H. (2019) Geographical concepts of vulnerability analysis for risk assessments - a review. Revista Publicando. Available at: https://leicester.figshare.com/articles/Geographical_Concepts_of_Vulnerability_Analysis_for_ Risk_Assessments_-_A_Review/10210148/files/18408011. pdf. (accessed 15 December 2019).

Roslee R., Jamaludin T. and Simon N. (2017) Landslide Vulnerability Assessment (LVAs): A Case Study from Kota Kinabalu, Sabah, Malaysia. Bangi Selangor. Malaysia: Indonesian Journal on Geoscience. pp. 49:59. Available at: https://www. researchgate.net/publication/315359632_Landslide_Vulnerability_Assessment_LVAs_A_Case_Study_from_Kota_Kinaba- 
lu_Sabah_Malaysia. (accessed 15 December 2019). https://doi. org/10.17014/ijog.4.1.49-59

Ruck M. (2008) Topics Geo - Natural catastrophes 2008, Analyses, assessments, positions. - Knowledge Series. p. 50. Available at: https://www.preventionweb.net/files/13201_topics2008.pdf. (accessed 26 February 2020).

Sam A., Khadijeh S. F. and Shojaei S. F. (2018) Land slide Hazard Zoning in Lahijan County Using Entropy and Multi Decision Making Promethee Methods. Mapping And Geospatial Information Journal Of Guilan. Available at: https://www.researchgate. net/publication/337759228_Land_slide_Hazard_Zoning_in_ Lahijan_County_Using_Entropy_and_Multi_Decision_Making_ Promethee_Methods. (accessed 22 February 2020).

Scribol (2010) Manshiet Nasser: The secret shame of Cairo's mega slum. Retrieved from Scribol: http://scribol.com/travel/ cities-travel/manshiet-nasser-the-secret-shame-of-cairosmega-slum/. (accessed 22 February 2020).

Slum Development Fund, M. (2016) General strategic plan for the development of the area of origin of Nasser - the first report studies of the current situation. Cairo: Ministry of Housing, Utilities and Urban Communities. p. 101. (accessed 15 April 2019).

Mrozek T., Laskowicz I., Zabuski L., Kulczykowski M. and Świdziński W. (2016) Landslide susceptibility and risk assessment in a non-mountainous region-a case study of Koronowo, Northern Poland. Geological Quarterly Institution. Available at: https://gq.pgi.gov.pl/article/view/24701. (accessed 19 february 2020). https://doi.org/10.7306/gq.1307

UN/ISDR. (2004). Living with Risk: A Global Review of Disaster Reduction Initiatives. 2004 version. available at: https://inis. iaea.org/search/search.aspx?orig_q=RN:33048155. (accessed 16 February 2020).

Vinnem J. E. and Røed W. (2019) Methodology for quantified risk assessment. offshore riskassessment Volume 2. Available at:https:// link.springer.com/chapter/10.1007/978-1-4471-7448-6_14. (accessed 15 February 2020). https://doi.org/10.1007/978-1-44717448-6_14

Westen C. V. (2014) Risk Analysis. Retrieved from available at: westen@itc.nl. (accessed 20 February 2020).

Zhang F., Chen W., Liu G., Liang S., He F. and Kang C. (2012) Relationships between landslide types and Topographic attributes in a Loess Catchment, China. Journal of Mountain Science. Available at: https://www.researchgate.net/publication/236615531_Relationships_between_Landslide_Types_ and_Topographic_Attributes_in_a_Loess_Catchment_China. (accessed 15 January 2020).

Zhou S., Chen G., Fang L. and Nie Y. (2016) GIS-Based Integration of Subjective and Objective Weighting Methods for Regional Landslides Susceptibility Mapping. Sustainability. Available at: https://www.mdpi.com/2071-1050/8/4/334/htm. (accessed 15 december 2020). https://doi.org/10.3390/su8040334 